\title{
The Development of Website on Management Information System for E-commerce and Services
}

\author{
Ahmad Tri Hidayat ${ }^{[1]^{*}}$, Andi Muhammad Dirham Dewantara ${ }^{[2]}$, Shoffan Saifullah ${ }^{[3]}$ \\ Department of Information System, University of Technology Yogyakarta ${ }^{[1],[2]}$ \\ Jl. Siliwangi (Ringroad Utara), Jombor, Sleman, 55285 \\ D.I. Yogyakarta, Indonesia \\ Department of Informatics Engineering, Universitas Pembangunan Nasional Veteran Yogyakarta ${ }^{[3]}$ \\ Jl. Babarsari No.2 Yogyakarta, 55281 \\ D.I. Yogyakarta, Indonesia \\ e-mail: ahmadth@staff.uty.ac.id ${ }^{[1]}$,dewantara2911@gmail.com ${ }^{[2]}$, shoffans@upnyk.ac.id ${ }^{[3]}$
}

\begin{abstract}
Currently, the sales system is overgrowing. The concept of selling that was done manually (which is still less than optimal) becomes electronic (e-commerce). System development requires a digital platform. This platform must be able to carry out all activities that were carried out before (manually), such as collecting documents, recording transactions, and reporting. Besides, the e-commerce platform can provide support and increased performance in the sales process, both in checking stock items, transaction reports, and services. Besides, this optimization can provide services precisely and quickly to consumers. A management information system concept is needed to carry out e-commerce and services with integrated data and be stored in its development database. This prototype concept requires a method for website development. The method used is a waterfall. Website design uses the Hypertext PreProcessor (PHP) programming language and MySQL database. The design model uses two concepts: entity-relationship diagrams (ERD) and data flow diagrams (DFD). The result is a website and e-commerce services that can be accepted by users and e-commerce organizers with tests that have been carried out. System testing uses Blackbox and Whitebox testing, each of which results can be used to implement e-commerce sites and services. The website can assist officers in service and e-commerce and make it easier for officers to determine the target and service status.
\end{abstract}

Keywords - E-commerce, Management Information System, Service, Waterfall, Website

\section{INTRODUCTION}

The development of trading companies today is very rapid. Various new platforms have emerged and can provide benefits in transactions [1]. The cause is the development of information and communication technology. Trading is often carried out manually (offline) [2], with bartering [3] and faceto-face [4]. People come to a shop or company to make transactions in person (face to face). Offline trading relies heavily on time and space for transactions. The person or organization changes the trading pattern that can be reached by, anytime, anywhere. It has currently developed using the internet platform, often referred to as e-commerce [5]-[7].

Many studies are related to e-commerce [8]-[11] and its development [5], [12]-[14]. E-commerce is in the form of buying and selling activities for products and services or sending funds or internet-based data. E-commerce provides speed and speed of the buying and selling process without limits on time and space. So that many people develop and implement this platform. It has an impact from offline (manual) trading to online.

Website development influences the e-commerce process. The factors that influence electronic commerce are competitive intensity, company size, and competence [15]. Thus, the improvement of the sales system from offline to online helps increase company competitiveness. Besides, it is necessary to improve competence in the competition, which is currently mostly online.

Related research has been carried out by developing a desktop-based system using Delphi 7 and MySQL [16], [17], but the process is still offline. This limitation increases competence and competence in online development. Besides, other desktop applications are using Visual Studio and SQL Server [18]. Based on the development of sales, online is currently a very significant increase. It aims to improve the company with the rapid growth of technology today.

This study aims to develop an e-commerce prototype in the CV. MX Computer. The platform is developed based on a website that can simplify the existing process. Also, users can perform or get services according to the business processes of the organization. The platform developed can provide better, faster, more precise, and efficient service than the previous process. This platform was created using the waterfall method in the software development cycle. The reference used in this article is the development of information systems with the concepts of ERP and RAD [19]. This website has a function as a marketing website, the differences are a real-time status check, and user communication (customers and employees). 
This article discusses four main points: introduction, methods, results and discussion, and conclusions. The introduction explains the background of the problem, literature review, and objectives. While the process of defining the development of e-commerce websites. The third section describes the results and discussion. Finally, in the fifth part, this section explains the conclusions and feature work.

\section{METHOD}

This section describes the methods and processes related to the process of developing an e-commerce website. The method used in developing the prototype is the waterfall method. Besides, the development concept uses several concepts, such as management information systems, websites, databases, and data flow.

\section{A. Sample data and tools requirements}

In the development of an e-commerce prototype using sample data from CV. MX Computer. Samples were taken by several methods, such as observation, interviews, and literature study. These observations use the process directly in place. The purpose of this observation is to determine the process and stages of sales that occur. Also, there is an interview process with employees. Interviews related to the system that happened and the development of a system prototype carried out. Regarding the result, it is necessary to conduct a literature study related to the development of ecommerce prototypes from all online and offline sources.

The development of e-commerce prototypes used website design tools with the Hypertext PreProcessor (PHP) programming language and a database with MySQL. The other devices can create design concept drawings for entity relationship diagrams (ERD) and data flow diagrams (DFD).

\section{B. Managemesnt Information System and the Developments}

Management Information Systems (MIS) is a system design in an organization related to resources, documents, technology, and management accounting in internal control strategies in business [20]. So that MIS is a collection of information system interactions for planning and controlling data in providing information for all levels of management.

In general, MIS can create information systems in data management [21], both storing, searching, and analyzing. The MIS is used to meet the needs of managers, staff, and customers. Thus, it is necessary to require information security, data integration, and data exchange.

One of the MIS developments in e-commerce is the activity of buying and selling products and services or sending funds or data via an electronic network (internet). This study uses the waterfall concept [22] for the development process of an e-commerce prototype. The waterfall flow is shown in Fig. 1 .

Based on Fig. 1, this study uses a process flow with four main functions, namely, requirements analysis, design, implementation, and testing. The first stage is carried out to determine the needs of the system being developed. The process includes research related to the ongoing procedure and needs analysis in the development of e-commerce prototypes.
Based on this analysis, the next step is designing. The design is carried out using the DAD and ERD concepts. DAD describes the data flow in the system, which is represented by each activity processes that can be carried out. Meanwhile, ERD is a concept in the design of data (entities) used in designing tables in the database. The ERD concept provides information related to relationships between related entities and attributes (complement).

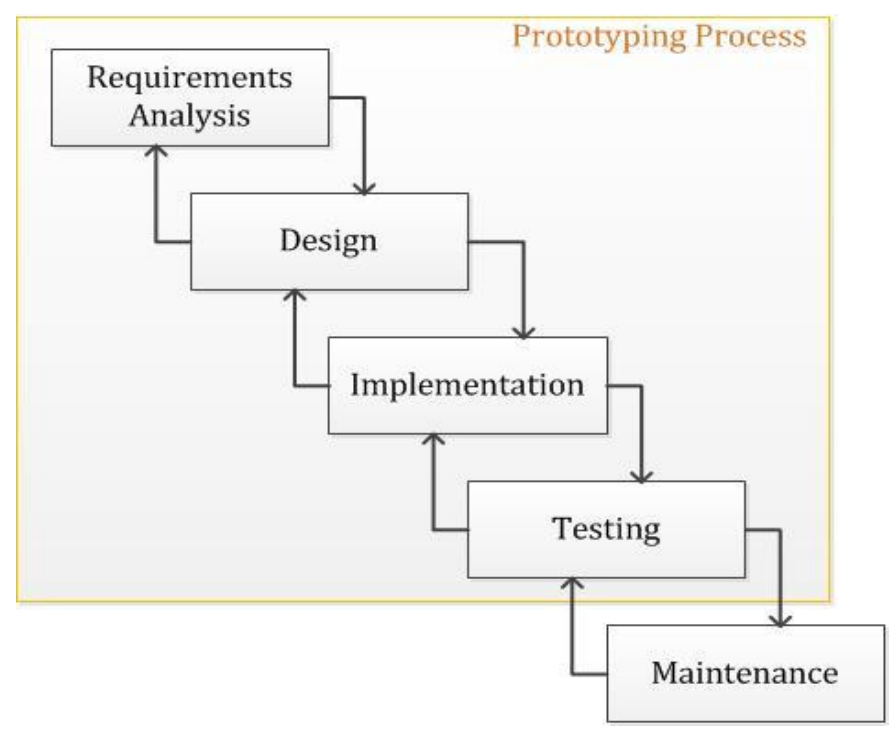

Fig. 1. The waterfall flow used in the development of e-commerce prototypes

The process includes research related to the ongoing procedure and needs analysis in the development of ecommerce prototypes. Based on this analysis, the next step is designing. The design is carried out using the DAD and ERD concepts. DAD describes the data flow in the system, which is represented by each activity processes that can be carried out. Meanwhile, ERD is a concept in the design of data (entities) used in designing tables in the database. The ERD concept provides information related to relationships between related entities and attributes (complement).

The implementation of the design is the application in the programming language PHP and MySQL. PHP is used for making e-commerce prototypes with the MySQL database. The performance of the system designed is then carried out by coding. The coding result is a website-based application. The website that has been created is subject to validation and verification so that the results of analysis, design, and implementation are interconnected and in sync.

The implementation result is a finished product. Before the implementation process, testing is necessary. System testing is carried out in two ways, namely Blackbox and Whitebox testing. Blackbox testing measures the success rate of the system based on the running of the application. Meanwhile, Whitebox testing tests the logic and content in the application.

\section{RESULTS AND DISCUSSION}

This section discusses the processes that have been carried out in developing an e-commerce prototype and its discussion. 
The results and discussion are in the form of system analysis, system design, system implementation (website application), and system test results.

\section{A. System analysis (current system running and system requirements)}

This study analyzed the system development process related to the current system and system development needs. The system currently running has two primary operations, namely service, and sales. The procedure service is carried out offline. Customers come to the shop and request for services. The services provided are in the form of receiving customer complaints and the process of repairing and responding to these complaints. This process must be conveyed directly to the technician for immediate processing with customer approval. The shop (marketing) will record service transactions. The service results are reported from the technician to the marketing for pricing to be conveyed to the customer.

The second procedure is sales, as is the case with the offline service procedure. Customers come to the shop to buy goods on the spot. If the item already exists, the customer can make a sales transaction. However, if the item does not exist, the customer can place an order in advance. After the goods are already there, the customer can return to the shop to make transactions for the item's purchase.

Based on these two processes, this shop still has shortcomings in making sales. Stores can only make transactions offline at a specific place and time. It is a reference for developing e-commerce prototypes to improve service to customers. Also, all data can be stored in a database that can be accessed anytime and anywhere.

This development requires two main requirements, namely: functional and non-functional. Applicable requirements are those that are directly related to the system. Thus, functional requirements must adjust to the users involved. The management information system's operational requirements in the service and e-commerce concept include input, transaction, and reporting processes. Meanwhile, nonfunctional requirements are supported in the system. These requirements emphasize the behavior properties of the system. The requirements needed are hardware and software. It is useful for analyzing the shortcomings and needs that must be met in system design.

\section{B. System design and implementation (Website Application)}

The e-commerce prototype developed was carried out by system design with two concepts, namely DFD and ERD. The DFD concept is illustrated with several drawings in general to specific and be created from the context diagram, up to the second level of DFD. The ERD concept is described to all entities associated with the analysis that has been done. Use ERD as a reference for creating tables in the database.

DFD in making an e-commerce prototype is depicted in five images starting from Figure 2. This design uses the rules from Valacich et al., (2012) [23]-[25]. Fig. 2 is a context diagram, which describes a general system overview, which consists of activities and data relating to the overall system.
Figure DFD is shown in Fig. 2 shows the data flow process starting from the context diagram (Fig. 2 (A)). The context diagram describes the system in general. The diagram aims to describe the input/output relationship between the system and the outside world. E-commerce applications made by entities are marketers, technicians, customers, and leaders. The processes that occur in the design, in general, are data management, service (management and checks), and reports, each of which is clearly shown in the context diagram. In the context diagram, it only describes an entity, a process, and a relationship line. The next design uses the DFD level 1 concept (Fig. 2 (B))

Fig. 2 (B) shows all entities' process details to the database system. All activities in the e-commerce system and services are described in more detail in this design. All entity components of the context diagram must match. Also, all of its activities are appropriate so that it becomes a sustainable system. In descending, existing processes at the first level DFD are lowered to the second level. At the second level, all operations are reduced to this level. The methods that are derived are material data (Fig. 2 (C)), transactions (Fig. 2 (E)), and reports (Fig. 2 (E)).

The principle of reduction in DFD is the same as the principle from context to the first level DFD. All entities that are related to the related process must be the same and appropriate (synchronous). So that from the design between contexts, DFD level 1 to level 2 (level $n$ ) must have the proper composition and activities.

In addition to DFD design, database design uses the ERD concept. This concept refers to the rules of Silberschatz et al. (2011) [25], [26]. The ERD showed in Fig. 3 (b) has three components, namely entities, relations, and constraints. Rectangles represent entities, rhombs represent relations. At the same time, lines/arrows depict the constraints. If only the line shows that the number is many $(\mathrm{M})$, the arrow indicates the constraint value is one (1). The ERD is not equipped with any attributes. Attributes are directly converted into a table shown in Fig. 3 (b), a table relation. This table relation is used for e-commerce application databases and services as a storage area.

Implementation of the design in the form of an application coding results using PHP and MySQL. Performance is tailored to exist in business processes. The existing methods are data management, transactions, and reports. Data management in ecommerce is customer goods, services and sales, incoming goods transactions, sales returns, active status checks, and sales and service reports. E-commerce applications are designed according to the design, which can perform all activities on DFD. Besides, the MySQL database is designed according to the ERD concept and the table relations that have been created. A visual e-commerce prototype is shown in Fig. 4.

Fig. 4 is an illustration of the e-commerce application prototype being developed. All users can carry out activities according to the rules created and designed in the ERD and DFD concepts so that this prototype has adjusted the business process and is following the waterfall rules. 

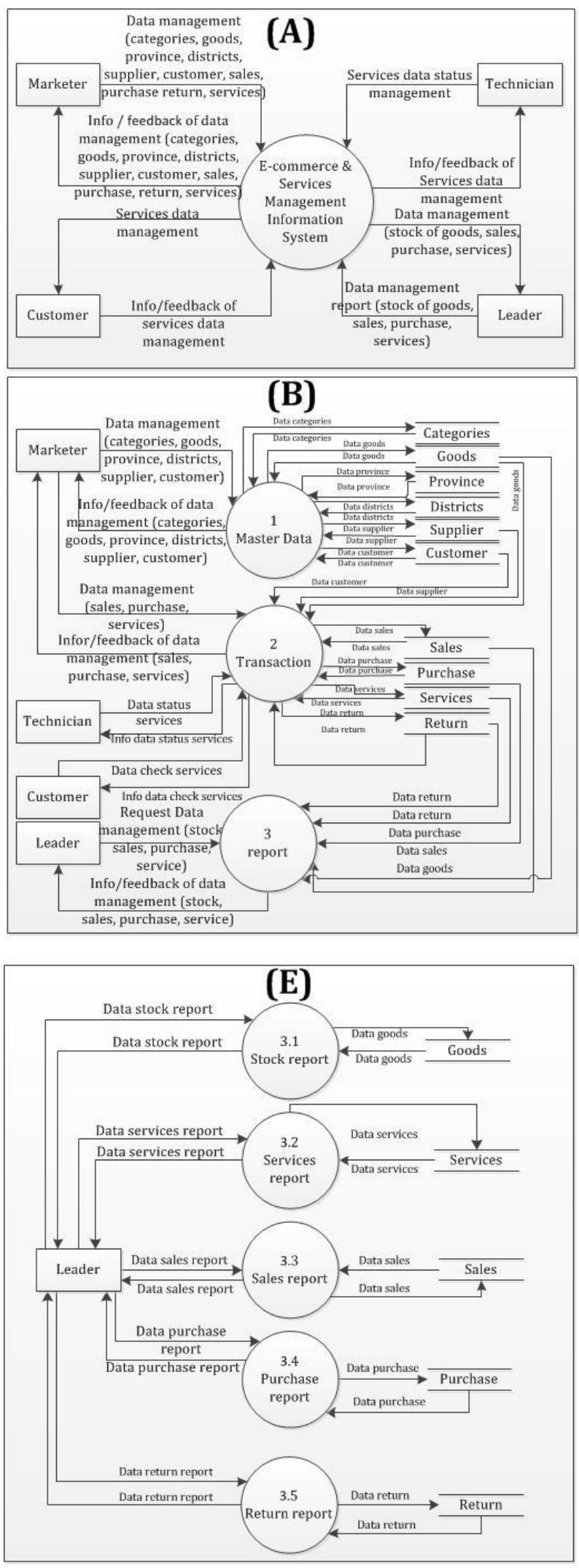
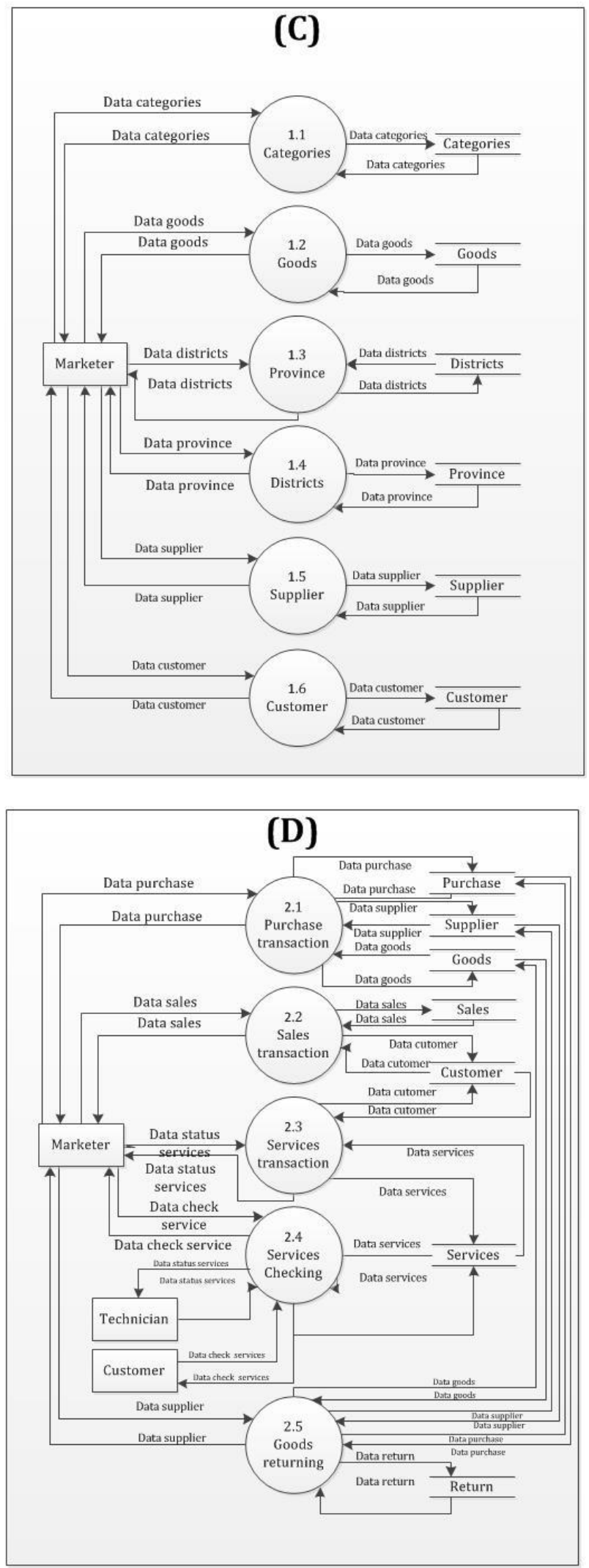

Fig. 2. DFD pictures in general to detail with (A) Context diagram (B) level 1 (C) level 2 process 1 (D) level 2 process 2 (E) level 2 process 3 for website application design (e-commerce)

p-ISSN 2301-7988, e-ISSN 2581-0588

DOI : 10.32736/sisfokom.v9i3.992, Copyright $@ 2020$

Submitted : 16 September 2020, Revised : 9 Oktober 2020, Accepted : 12 Oktober 2020, Published : 20 Oktober 2020 


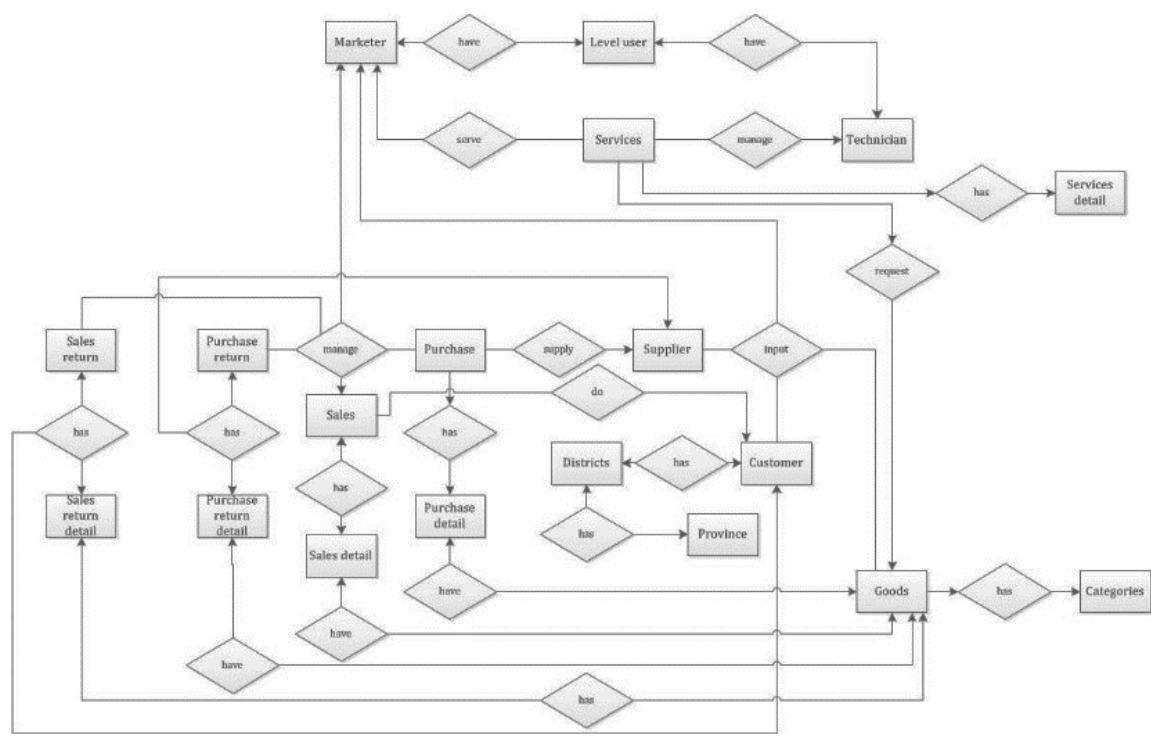

(a)

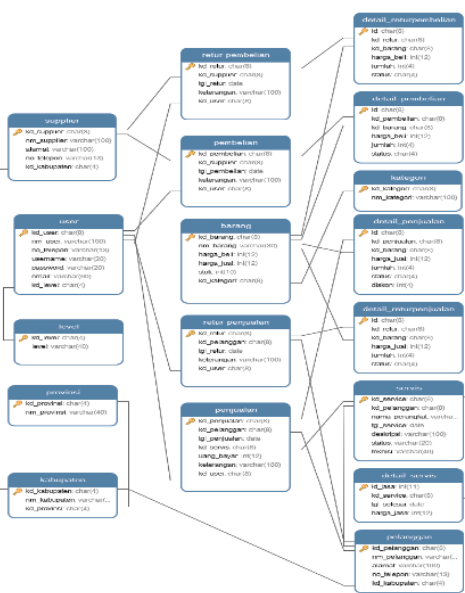

(b)

Fig. 3. Database planning with (a) ERD concepts and (b) table relations

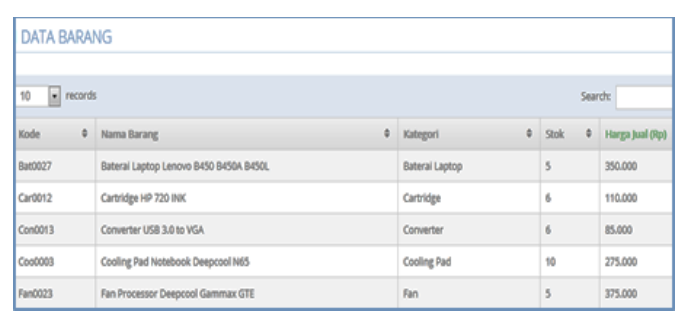

(a)

\begin{tabular}{|c|c|c|c|c|}
\hline \multicolumn{5}{|c|}{ DATA SUPPLIER } \\
\hline \multicolumn{5}{|c|}{ ADD DATA } \\
\hline No & Numo Supples & Nebupptenkota & Nemat tenctap & No Telepon \\
\hline 1 & insomedou & vegeleats & A Mageleng km5 no 125 & 027474850000 \\
\hline 2 & Holero Competama & rogediarto & A. Nologiten Ct.14 & 02745535095 \\
\hline 3 & Grossom & semen & A. Getpon Ge Sung Na 8 & 0274663535 \\
\hline 4 & GOLENTECH & seman & A. Cendana no 15 barang sem bav & 0274742315 \\
\hline
\end{tabular}

(c)

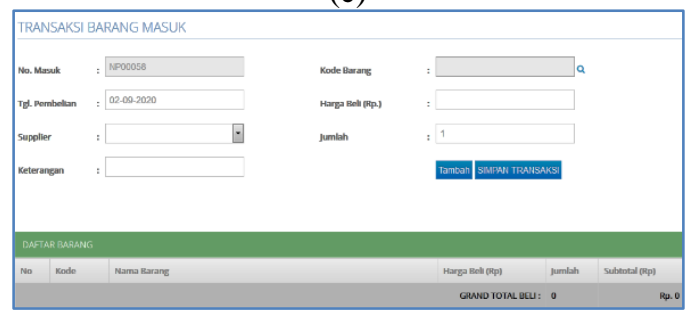

(e)

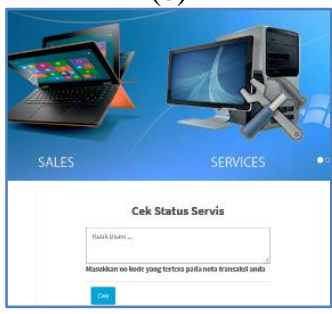

(g)

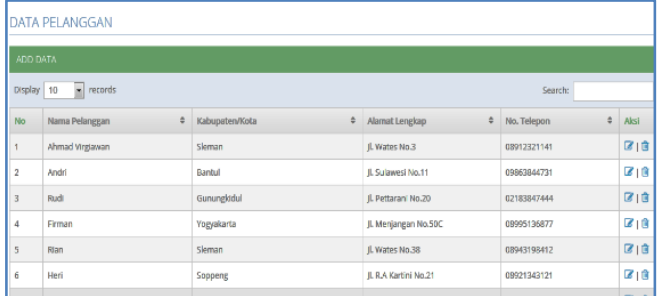

(b)

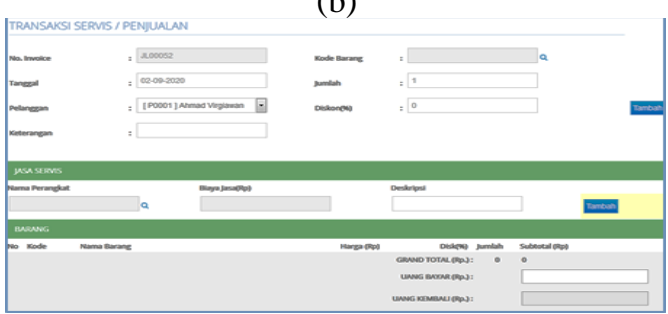

(d)

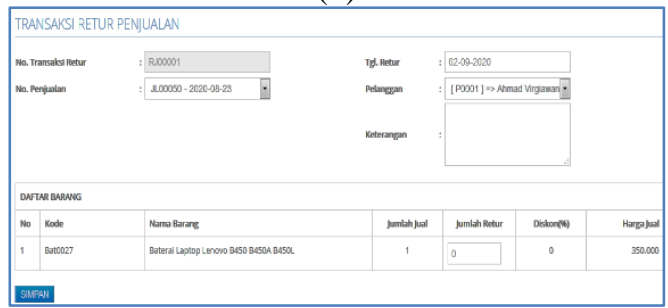

(f)

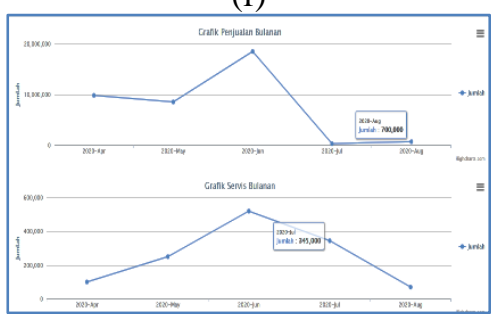

(h)

Fig. 4. Implementation of e-commerce applications and services with data management of (a) goods, (b) customers, (c) suppliers, (d) service and sales, (e) incoming goods transactions, (f) sales returns, (g) checking status active, and (h) sales and service reports graph 
TABLE I. RESUlts OF THE BLACKBOX AND WhiteBoX TESTING BASED ON THIS ASPPLICATION SECTION

\begin{tabular}{|c|c|c|c|}
\hline \multirow{2}{*}{ No } & \multirow{2}{*}{ App section } & \multicolumn{2}{|l|}{ Testing methods } \\
\hline & & Blackbox & Whitebox \\
\hline 1 & $\begin{array}{l}\text { Goods; } \\
\text { customer }\end{array}$ & $\begin{array}{l}\text { The search, input, update, delete, record data display, sorting buttons can } \\
\text { function and process as expected. Besides, the form can be filled in according } \\
\text { to existing data and successfully processed. }\end{array}$ & $\begin{array}{l}\text { All existing process flows can execute code commands } \\
\text { according to existing business processes and designs. } \\
\text { The resulting logic is suitable and acceptable. }\end{array}$ \\
\hline 2 & Supplier & $\begin{array}{l}\text { The add data button displays a data entry form that can be filled to add it. The } \\
\text { form can be filled in as needed. For example, the number phone is inputted } \\
\text { with a numeric. Otherwise, it will display the wrong format verification and } \\
\text { must be changed. Likewise, editing and deleting is done by clicking the desired } \\
\text { data. All processes are running properly. }\end{array}$ & $\begin{array}{l}\text { The process flow of add, update, and delete data has a } \\
\text { simple code that starts from inputting the required data, } \\
\text { then processing it according to the command, for } \\
\text { example, add will save it into the database. When } \\
\text { canceled, the data is not saved. }\end{array}$ \\
\hline 3 & $\begin{array}{l}\text { Service and } \\
\text { sales } \\
\text { transactions }\end{array}$ & $\begin{array}{l}\text { Add button can add transaction processing. This section has six forms that can } \\
\text { be filled in by the clerk. There are 5, for the system automatically fills in } \\
\text { invoice numbers. The item code will search according to the existing database, } \\
\text { the amount, and discount in the form of numbers. Besides, some customers are } \\
\text { taken from the customer database and information entries. The function of each } \\
\text { component is by its purpose. The output written in the summary below for the } \\
\text { payment process is inputted with the amount paid. Then also can add the } \\
\text { desired services }\end{array}$ & $\begin{array}{l}\text { Process logic flow in coding according to business } \\
\text { processes. The flow is coherent and can run as } \\
\text { expected. Existing processes include adding transaction } \\
\text { data, where data has been added and calculated for } \\
\text { determining sub-totals and totals, for payment. The } \\
\text { calculation results are correct and suitable for } \\
\text { transaction processing. }\end{array}$ \\
\hline 4 & $\begin{array}{l}\text { Incoming } \\
\text { goods } \\
\text { transactions }\end{array}$ & $\begin{array}{l}\text { There are only two buttons, namely, add and save transactions. Add to add data } \\
\text { in a temporary database. Save is used to save existing data to the database. The } \\
\text { form can be filled in according to the existing rules. The number is entered } \\
\text { automatically from the system, the date that the current default is made, the } \\
\text { supplier and the item code is retrieved from the database, the price and quantity } \\
\text { use the number. Everything can run according to conditions. }\end{array}$ & $\begin{array}{l}\text { The flow of storage for the incoming goods transaction } \\
\text { process is by the coding flow, in which data is added } \\
\text { and stored by the fields entered into the database. }\end{array}$ \\
\hline 5 & Sales returns & $\begin{array}{l}\text { The return process only has a save button. It is related to sales and customers. } \\
\text { The data is taken from the seller and the customer in the fields, and contains } \\
\text { dates and information. The default date for the current date. }\end{array}$ & $\begin{array}{l}\text { Processing of goods returns begins by filling in the data } \\
\text { according to its contents, then entering the list of } \\
\text { returned goods. After that, it is stored in the database. } \\
\text { Data saved and successful. }\end{array}$ \\
\hline 6 & $\begin{array}{l}\text { Check } \\
\text { services status }\end{array}$ & $\begin{array}{l}\text { There is only a form and one check button. The form must be filled with the } \\
\text { transaction code. }\end{array}$ & $\begin{array}{l}\text { The data that is filled in will be checked in the } \\
\text { database; if there is any, it will provide service } \\
\text { information, while if there is no, it will notify that there } \\
\text { is no service process. }\end{array}$ \\
\hline 7 & Report graph & $\begin{array}{l}\text { There is a setting button to display sales and service data with a selected grace } \\
\text { period. The button can be selected and executed and can run well. }\end{array}$ & $\begin{array}{l}\text { The process carried out is merely displaying a graph } \\
\text { according to sales and service data from the database. }\end{array}$ \\
\hline
\end{tabular}

The system testing process (Table 1) that is carried out ensures that all the concepts made in the prototype can carry out the process as they should. The test results show that the ecommerce website can run smoothly following existing business processes. Besides, the logic in the system also runs according to the rules. Thus, after testing, this prototype can be implemented. In line with that, it is necessary to carry out maintenance in its development.

Based on the explanation above, the system will be implemented in the case study. The application can make all of the rules and activities that were designed.The system that has been developed can produce the following provisions.

a. Checking stock items and transaction reports are easily accessible through a web-based information system built, making it easier for leaders to monitor ongoing transactions and control the availability of stock items.

b. The resulting web-based information system provides a feature to display service status that can help officers determine service targets. The website makes it easier for customers to know the status of computer service work in progress or the computer can be retrieved.

c. The web-based computer sales and service management information system can integrate computer service and sales service data, thus helping officers provide services that are more effective, fast, and accurate.

\section{CONCLUSION}

The prototype that has been developed contributes to the development of the e-commerce platform in handling buying and selling services. All transactions in sales can be done online to facilitate access, commerce, and services. This prototype platform makes it easier for all users, customers, servants, and leaders to run the application. All the features in the application have been tested, which can be accepted in the testing. In the future, this prototype platform can be implemented in related agencies. Besides, data security features with a secure sockets layer (SSL) is added for the encryption process.

\section{ACKNOWLEDGMENT}

Thank you to the University of Technology Yogyakarta for contributing to the completion of the article and research. Do not also forget to thank UPN Veteran Yogyakarta, who has helped provide informatics lecturers for this article's production.

\section{REFERENCES}

[1] W. Reinartz, N. Wiegand, and M. Imschloss, "The impact of digital transformation on the retailing value chain," Int. J. Res. Mark., vol. 36, no. 3, pp. 350-366, Sep. 2019, doi: 10.1016/j.ijresmar.2018.12.002.

[2] V. Wohlgemuth, E. S. C. Berger, and M. Wenzel, "More than just financial performance: Trusting investors in social trading," J. Bus. Res., vol. 69, no. 11, pp. 4970-4974, Nov. 2016, doi: 10.1016/j.jbusres.2016.04.061. 
[3] S. Cho, C. Park, and J. Kim, "Leveraging Consumption Intention with Identity Information on Sharing Economy Platforms," J. Comput. Inf. Syst., vol. 59, no. 2, pp. 178-187, Mar. 2019, doi: 10.1080/08874417.2017.1326295.

[4] B. Werse et al., "Sharing, Group-Buying, Social Supply, Offline and Online Dealers: how Users in a Sample from Six European Countries Procure New Psychoactive Substances (NPS)," Int. J. Ment. Health Addict., vol. 17, no. 5, pp. 1237-1251, Oct. 2019, doi: 10.1007/s11469018-0043-1.

[5] J. Kwak, Y. Zhang, and J. Yu, "Legitimacy building and e-commerce platform development in China: The experience of Alibaba," Technol. Forecast. Soc. Change, vol. 139, pp. 115-124, Feb. 2019, doi: 10.1016/j.techfore.2018.06.038.

[6] W. Liu, J. Zhang, S. Wei, and D. Wang, "Factors influencing organisational efficiency in a smart-logistics ecological chain under ecommerce platform leadership," Int. J. Logist. Res. Appl., pp. 1-28, Apr. 2020, doi: 10.1080/13675567.2020.1758643.

[7] L. Scarcella, "E-commerce and effective VAT/GST enforcement: Can online platforms play a valuable role?," Comput. Law Secur. Rev., vol. 36, p. 105371, Apr. 2020, doi: 10.1016/j.clsr.2019.105371.

[8] F. Aulkemeier, M. A. Paramartha, M.-E. Iacob, and J. van Hillegersberg, “A pluggable service platform architecture for e-commerce," Inf. Syst. Ebus. Manag., vol. 14, no. 3, pp. 469-489, Aug. 2016, doi: 10.1007/s10257-015-0291-6.

[9] K. C. Laudon and C. G. Traver, E-commerce: business, technology, society. 2016.

[10]H. Aggarwal and S. Jain, "E-Commerce in India," E-Commerce India Econ. Leg. Perspect., p. 36, 2020.

[11] Y. Cui, J. Mou, J. Cohen, and Y. Liu, "Understanding information system success model and valence framework in sellers' acceptance of crossborder e-commerce: a sequential multi-method approach," Electron. Commer. Res., vol. 19, no. 4, pp. 885-914, Dec. 2019, doi: 10.1007/s10660-019-09331-0.

[12]H. Wang, "The Balanced Scorecard Study on the Corporate Social Responsibility of Electronic Commerce," in Modern Organisational Governance, vol. 12, Emerald Publishing Limited, 2017, pp. 161-185.

[13] A. V. Barenji, W. M. Wang, Z. Li, and D. A. Guerra-Zubiaga, "Intelligent E-commerce logistics platform using hybrid agent based approach," Transp. Res. Part E Logist. Transp. Rev., vol. 126, pp. 15-31, Jun. 2019, doi: 10.1016/j.tre.2019.04.002.

[14]Y. Wang, Z. Yu, and M. Jin, "E-commerce supply chains under capital constraints," Electron. Commer. Res. Appl., vol. 35, p. 100851, May 2019, doi: 10.1016/j.elerap.2019.100851.
[15]N. Rao Kowtha and T. Whai Ip Choon, "Determinants of website development: a study of electronic commerce in Singapore," Inf. Manag., vol. 39, no. 3, pp. 227-242, Dec. 2001, doi: 10.1016/S03787206(01)00092-1.

[16]V. M. Sudhana, "Sistem Informasi Servis Dan Penjualan Sparepart Komputer Pada Toko Multinet Computer,” Kediri, 2017.

[17]M. Burrohman, "Membangun Sistem Jual Beli Dan Servis Laptop Berbasis Client Server (Studi Kasus Toko Salamah Komputer Komplek Ruko Rame Mall Yogyakarta)," Yogyakarta, Indonesia, 2018.

[18]Hendra, "Sistem Informasi Manajemen Penjualan Dan Servis Komputer Pada CV. Justin Komputer,” Palembang, Indonesia, 2016.

[19] Sunardi, A. Fadlil, F. Al-anshori, and S. Saifullah, "Information System Development Based-on ERP and RAD Methods: Application for Activities Information Broadcasting," JUITA J. Inform., vol. 8, no. 2, 2020.

[20]E. Alomari et al., "Analyzing, Designing and Implementing a Consulting Company for Management Information Systems," ALOMARI, E., ALSHAMMRY, M., ALHAMIL, S., ALSMADI, MK, ALSHABANAH, M., ALRAJHI, D., ALMARASHDEH, I. ELJAWAD, L, pp. 422-432, 2019.

[21]A. V. Usman and F. N. Ogwueleka, "SDLC Models as Tools in the Development of MIS: A Study," IUP J. Inf. Technol., vol. 14, no. 4, pp. 52-59, 2018

[22]K. Chari and M. Agrawal, "Impact of incorrect and new requirements on waterfall software project outcomes," Empir. Softw. Eng., vol. 23, no. 1, pp. 165-185, Feb. 2018, doi: 10.1007/s10664-017-9506-4.

[23] J. S. Valacich, J. F. George, and J. A. Hoffer, Esentials of Systems Analisis \& Desain, 5th ed. E-Books: Prentice Hall Upper Saddle River, NJ, 2012.

[24] S. Saifullah and A. Hermawan, "Sistem Penjadwalan Kuliah Berbasis Click and Drag (Studi Kasus di Fakultas Sains \& Teknologi Universitas Teknologi Yogyakarta)," J. Tek. Inform. dan Sist. Inf., vol. 3, no. 1, pp. 31-45, 2017, doi: https://doi.org/10.28932/jutisi.v3i1.652.

[25] S. Saifullah and A. Hermawan, "Pengembangan Sistem Penjadwalan Kuliah Menggunakan Algoritma Steepest Ascent Hill Climbing," J. Sist. Komput., vol. 6, no. 2, pp. 57-62, 2016.

[26]A. Silberschatz, H. F. Korth, and S. Sudarshan, Database System Concepts, 6th ed. (alk. paper) E-book, 2011. 